\title{
The Effect of Climate Change on Agricultural Crop Returns in Uganda
}

\author{
Geoffrey Norman Tumwine ${ }^{1 *}$, Razack B Lokina ${ }^{1}$, John Mary Matovu ${ }^{2}$ \\ ${ }^{1}$ Department of Economics, University of Dar es Salaam, Dar es Salaam, Tanzania \\ ${ }^{2}$ Reseach for Transformation and Development, Kampala, Uganda \\ tumnorm@gmail.com,rlokina@udsm.ac.tz, jmatovu@gmail.com
}

\begin{abstract}
The study examined the effect of climate change on agricultural crop returns in Uganda using the Ricardian Panel Tobit technique and the World Bank Living Standards Measurement Survey (LSMS) data, climate data from Uganda National Meteorological Authority (UNMA) and global weather data. The findings showed that climate related risks account for over 67 percent of agricultural risks and less than 2 percent of the farming households practise irrigation. Farmers that practised irrigation earned higher agricultural returns nationally than their counterparts did. The findings show that the output elasticities with respect to temperature range from -2.02 percent to 0.543 percent. This implies that for the average temperature increase by 1 percent, maize farm returns decreased by 2.02 percent, banana by 1.7 percent, cassava by 1.50 percent and beans by 1.01 percent. While 1 percent increases in rainfall, lowered banana returns by 0.02 percent, beans by 0.08 percent, cassava by 0.035 percent, maize by 0.025 percent except for groundnuts' returns increased by 0.115 percent. Apart from climate factors, non-climate factors such as capital, labour, farm size, fertilizers and soil quality are equally important inputs and significantly impact on agricultural farm returns. The study proposes that due to unrelenting adverse climate change effects in Uganda, adoption of multi-pronged approaches such as extensive irrigation, agro-insurance, diversification of agricultural activities, use of food cribs during bumper harvests would be the breath of life for Ugandan farmers.
\end{abstract}

Keywords: Climate change, agriculture, crop returns, Ricardian model and panel Tobit model.

\section{Introduction}

Global climate has warmed since 1950s and anthropogenic influence is the most likely dominant cause (IPCC, 2014; Angélil et al., 2017). Global surface temperature in 2016 shot up by $1.0^{\circ} \mathrm{C}$, making it the warmest year ever relative to 1951-80 base period (Hansen et al., 2019). With intermittent global warming, ice sheets, glaciers, snow cover and permafrost have significantly decreased in area and volume. In many regions, historical droughts and floods have been ever more severe since 1900. Tropical cyclones, hailstorms, thunderstorms, wave heights have soared since 1970s. As a result, the undulating climate change has affected water resources, food and agricultural systems globally (Hanjra \& Qureshi, 2010; Nielsen \& Vigh, 2012; Teixeira et al., 2013). In Sub-Saharan Africa (SSA) where the majority of the population depends on climatesensitive agriculture (World Bank, 2010), the frequency of meteorological disasters have caused both prevalent economic and life losses in the region (Gasper et al., 2011; Thurlow et al., 2012) and derailed poverty alleviation efforts (Dell et al., 2009; Skoufias, 2012). Evidence also shows that exposure to high temperatures reduces work capacity and labour productivity (Zivin \& Neidell, 2014; Dunne et al., 2013). The preceding impacts are likely to have unequal distribution globally, with developing countries at disadvantage, given their geographical position, limited resources, and low adaptive capacities (Peña-López, 2009).

Africa contributes the least amounts of greenhouse gases; making it the least responsible for climate change, but it experiences the worst effects of climate change (Sy, 2016). Uganda is one of the agriculture-dependent economies in SSA where climate change manifestations have been real. The reviewed literatures of IPCC (2013; 2014), Caffrey et al. (2013) and Guloba (2014) affirm that climate change has taken place in Uganda, hence this study did not need to spend time on fishing expedition with no major fish to catch. Over the past three decades spanning from 1981 to 2010, the country experienced substantial increase in temperature ranging from $0.5^{\circ} \mathrm{C}$ to $1.2^{\circ} \mathrm{C}$ (Caffrey et al., 2013). In addition, GoU (2015) documents that for the period ranging from 2010 to 2014, Uganda's GDP on average decreased by 3.5 percent due to natural disasters such as floods, landslides, drought, famine, severe storms and earthquakes. The natural disasters destroyed hectares of crops, causing huge economic losses to the economy amounting to USD 1.2 Billion between 2010 and 2011. In farming communities, men go far away to look for pastures, while women walk longer distances in search of water and firewood, limiting the time for agricultural production. Due to adverse weather related factors, Uganda's GDP contracted by 0.2 percent in the first quarter of the Financial Year 2016/2017. 
This was majorly due to a contraction of the agricultural sector, which was consistent with the relatively feeble growth in household incomes (BoU, 2018). The continued occurrence of climate change effects severely undermines the growth prospects of the country and consequently deters the realization of the country's Vision 2040. The solution to manage and mitigate climate change effects lies in understanding its effect. However, there is limited empirical analysis on the hurtful upshots of climate change on agricultural crop returns. The only known study by Matovu (2013) used cross-sectional Ricardian analysis approach. The use of cross sectional data is limited given that climate change coefficients vary over time, also there are distortions emanating from the correlations between climatic variables, and farmer's adaptation strategies (Thomson, 2010). Numerous studies on the climate change- agriculture nexus in the region have ignored a subtle and prevalent fact of "nothingness" or "missingness" of agricultural output in their analysis, caused by climate related risks such as drought, floods. This study employs a modified version of panel called pane Tobit analysis to address this omission. The paucity of analytical work on climate change impact affects the costbenefit analysis interventions to mitigate effects. It is against this background that the study sets out to examine the effect of both rainfall and temperature on crop returns in Uganda.

\section{Literature Review}

The longing to analyse the effect of climate change on agricultural returns led to the advent of the Ricardian theory as credence. The motivation for the development of the Ricardian analysis according to Mendelsohn et al. (1994) based on the bias that tends to overestimate the damage of climate change embedded in the traditional production function method initially used in the studies of Adams et al. (1988), Adams et al. (1998) and Rosenzweig \& Parry (1994). The traditional production function estimated impact of climate change by altering few input levels such as precipitation, temperature and carbon oxide levels. It omitted a variety of adaptations customarily used by farmers to mitigate the effects of climate change. Similarly, Easterling et al. (1993) ignored adaptations such as application of fertilizers, use of irrigation, introduction of new crops in the region, use of new technology, shifts in land use from farming to livestock, or from planting rice to fruit farming. Mendelsohn et al. (1994) use an illustration in Figure 1 to explain the bias using values of various activities and temperature.

Figure 1: Bias in the Production Function Adapted from Mendelsohn et al. (1994)

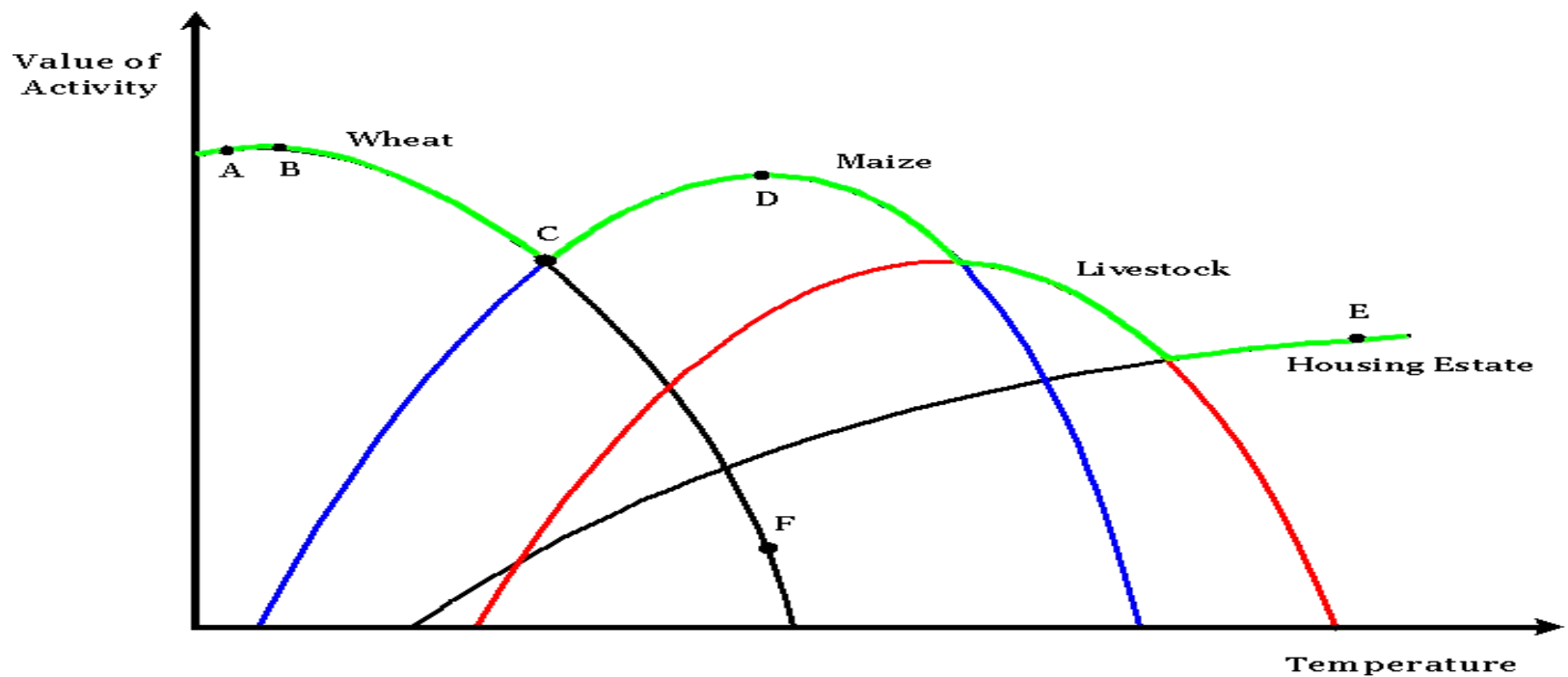

The functions shown in the figure illustrate how the values of wheat, maize, and livestock respond to temperature increases. For example, the "wheat production function" shows how the value of wheat responds to temperature increases from point A to peak B and finally decreases as temperatures shoot up. Mendelsohn et al. (1994) cite the source of the bias as the failure to allow for economic substitution as temperatures rise. For instance, for temperature above $\mathrm{C}$, adaptive and profit- maximizing farmers would replace wheat with maize. With temperature increases, the wheat production function estimates output to fall to point $\mathrm{F}$, yet in 
reality farmers no longer produce wheat, and however, it would be profitable to produce amount D of maize at the same temperature. With increased temperature, land is no longer optimal for maize growing. Lastly, at point E, agricultural model predicts that neither farming nor livestock is worth undertaking. The most prudent activity would be to convert land to housing estate as per Figure 1, however, given the expensive nature of developing the housing estate; it is neither affordable nor optimal scheme for Uganda's case. The most appropriate strategy would be adoption of adaptation strategies such as irrigation in case temperatures increase persistently overtime. Mendelsohn et al. (1994) infer that the traditional function overestimates the damages of climate change because it does not take into account the myriad options of substitution, adaptation, and new options of replacing the old-no-longer -advantageous activities as climate varies. To address the bias Mendelsohn et al. (1994) recommend a new approach called the Ricardian that permits options of adaptation like use of fertilizers, switching the use of land such that farmers lessen the severity of damage of climate change. Figure 1 illustrates the value of the net yield per acre of land measured along the vertical axis.

The green lines represent the best-use value function. Mendelsohn et al. (1994) term the approach Ricardian because of the focus on the land values ${ }^{1}$. The Ricardian analysis employs regression method to analyse the effects of various climate, economic, and other factors on farm values (Adams et al., 1998; Sanghi, et al., 1998). According to Mendelsohn et al. (2010), the model is easy to estimate, yields geographically precise values and captures adaptation. Further, it satisfies the key properties of economic models such as parsimony, tractability, empirical consistence and predictive precision as explained by Friedman \& FRIEDMAN (1953) and Jasso (2004). Empirical evidence shows that temperature is a major factor affecting the growth of crops, for instance Tian et al. (2014), reveal that rises in winter warming, increase wheat yield in China. Increase of all-day, daytime and night time mean temperature by $1.5^{\circ} \mathrm{C}$ reduced the length of preanthesis period averagely by $12.7,8.3$ and 10.7 percent respectively, and increased grain yield by $16.3,18.1$, and 19.6 percent respectively. While Hou et al. (2012) found that increasing temperature by $1.6^{\circ} \mathrm{C}$, increased wheat production. In contrast, Fang et al. (2013) in their experiment with warming of $2^{\circ} \mathrm{C}$ and irrigation of $100 \mathrm{~mm}$, find that warming decreases yield, but increasing irrigation by $200 \mathrm{~mm}$, increases wheat yield. This clearly emphasizes the importance of irrigation. Asseng et al. (2011) carry out an investigation in Australia to assess the effect of temperature on wheat yield. They find that each additional day of temperature above $34^{\circ} \mathrm{C}$ in any region of Australia on average; reduces grain yields by 5 percent. Inferably, one argues that rising temperatures lower soil moisture content, subsequently decrease output.

In Nigeria, Ayinde et al. (2010) using time series data from 1987 to 200, found that agricultural values were independent of temperature but highly dependent on rainfall variations. They recommend that government intervention with appropriate policies can mitigate climate change effects. However, without SSA governments increasing agriculture budgetary allocations to 10 percent as resolved in the Maputo declaration (Union, 2003), the adverse effects of climate change may exacerbate. Benin (2015) reveals that Niger and Malawi met the budgetary allocation to agriculture sector. Maganga \& Malakini (2015) use a quintile Ricardian Analysis to estimate the economic impact of climate change on agriculture in Malawi. They use the cross-sectional data on climate, soil, hydrological and household level data with a sample size of 8,832 households. Their findings show that climate had effect on net farm revenue, non-linear relationship between temperature and revenue existed, so is precipitation and revenue. The empirical results show that an increase of warming by $2.5^{\circ} \mathrm{C}$ magnifies the losses up to US $\$ 0.018$ billion. Reducing rainfall by 7 percent lowers net revenue by approximately 8.13 percent per hectare. However, the use of cross-sectional data in the analysis of the effect of climate change on agricultural production disregards the premise that cross sectional climate coefficients change overtime (Thomson, 2010). Fezzi \& Bateman (2012) use panel Ricardian analysis in the United Kingdom to analyse the non-linear effects of climate change on agricultural production. The results show a significant non-linear interaction effect, with high levels of rainfall acting as a moderating factor for increased temperatures.

\footnotetext{
${ }^{1}$ Mendelsohn et al. (1994) based on David Ricardo who developed the theory of the rent of land in the book titled Principles of Political Economy and Taxation in 1817. He said rent tends to increase as population grows. Premised on a fact that with diminishing returns to land, the magnitude costs of cultivation rise and with its rent.
} 
When they compared the results of other competing models that used aggregated data across regions, the results showed a strong bias afflicting climatic coefficients based on aggregated data and hence the desire for use of econometric Ricardian panel data approach. Further, higher temperatures positively increase agricultural production or land values amidst sufficient precipitation that thwart the risk of drought. Empirical results show that developing countries are hit hardest by adverse effects of climate change compared to the rest of the globe. Exenberger et al. (2014) use a panel of about 127 countries for the time spanning from 1961 to 2002. The findings show that climate change had no significant impact on agricultural production across a spectrum of high-income countries, however a significant harmful effect on both middle and low-income countries. The negative consequences of rising temperature and frequent reductions in rainfall lower agricultural output in developing countries. The adverse effects were strongest in SSA due to over reliance on rain-fed agriculture with minimal adaptation strategies. The results show that moderate moisture increases are conducive for food production unlike excess moistures. They use total livestock units as one of the regressors.

However, including total livestock units as a regressor, assumes livestock as climate change neutral, yet temperature increases and excessive rainfall have significant impact on livestock. Similarly, Bezabih et al. (2014) use the number of oxen as one of independent variables in the study carried out in Ethiopia, but Skonhoft (2008) treats livestock as capital goods. Kurukulasuriya \& Ajwad (2007) estimate the Ricardian model and treat the dependent variable as composite of agricultural returns from both livestock and crops in the study carried out in Sri Lanka. This methodology too creates difficulty in discerning which is more vulnerable to climate change between livestock and crop husbandry. In conclusion, this section reviewed literatures on the impacts of climate change on agricultural returns using the econometric Ricardian analysis. Further, classical economics identifies labour and physical capital as major sources of growth or output. Strangely, most studies exclude these traditional and vital sources of growth in their analyses. All studies reviewed show that agricultural production is nonzero, yet agricultural risks such as storms, droughts and floods cause total destruction with no harvest. This study considers this fact and uses panel Tobit model. The study attempts to address these existing gaps spotted during literature reviews.

\section{Methodology}

The most appealing technique to measure the effect of climate change on agriculture is the Ricardian technique due to its knack to use extensive country-level farm data. Studies of Mendelsohn et al. (1994), Massetti \& Mendelsohn (2011) and, Fezzi \& Bateman (2012) provide a motivation to use the Ricardian approach instead of the traditional production function or agronomic models. Other methods underestimate positive effects and overestimate the negative effects of climate change due to their failure to account for adaptation choices such as use of irrigation and switching of crops, options often adopted by farmers amidst climate pressures. Several studies to empirically examine the impact of climate change on agriculture using Ricardian approach have varied quite heterogeneously in terms of; (i) data, cross-sectional versus panel data, and country-level versus household-level; (ii) methods; Computable General Equilibrium (CGE) versus partial equilibrium; and (iii) focus; regional versus country- specific (Skoufias, 2012). Further, modified applications include individual farm data and various functional forms that are more versatile and flexible (Salvo et al., 2014).

A proper scrutiny of these studies shows that the Ricardian method is a profoundly common estimation procedure used in microeconomic studies. Mendelsohn et al. (1994) originally proposed it because of its prominence over the traditional production function approach. It has continuously gained a wide scope of application because it is easy to estimate, gives geographically precise values and permits use of adaptation strategies like irrigation. Therefore, the paper employs the Ricardian method to assess the effect of climate change on agricultural returns. The original Ricardian model used cross-sectional data to analyse the impact of climate, change on land values (Mendelsohn et al., 1994). Multitudes of studies that have applied the Ricardian method using cross-sectional data have yielded the results that are not stable over time (Deschenes \& Greenstone, 2006). They instead propose use of panel data models since coefficients are constant over time. This discovery enables researchers to analyse climate change without having to consider a time span of 30 years since climate coefficients are constant overtime. Salvo et al. (2014) also supplement that a panel data approach removes year effects and produces more stable estimates of climatic coefficients. 
However, basing on their methodology used in their study, there is a likely possibility that agricultural output in SSA was underestimated since most households are subsistence based yet their estimations were market based. Kabubo-Mariara et al. (2016) analyse the climate change impact on food production in Kenya using the Ricardian panel approach. The choice of econometric panel Ricardian model amongst other competing models is due to the following reasons. First, climate coefficients change often over time (Thomson, 2010). Second, it is possible to have biased estimates if the dependent variable is the farms' net revenue measured in unrepresentative year. Third, panel data eliminates the distortions caused by the correlation between climatic variables and farmer's strategies treated explicitly in the model such as irrigation (Salvo et al., 2014). Fourth, the model apart from climate variables such as temperature and rainfall, includes other factors such as capital, labour, adaptation choices, namely use of irrigation and application of fertilizers. As a result, several studies have used panel data (Lang, 2007; Massetti \& Mendelsohn, 2011; Fezzi \& Bateman, 2012). Therefore, given the eminence of panel over the cross-sectional data models, the study adopted panel data to analyse the impact of climate change on agriculture. Secondly, availability of panel data in Uganda aids the undertaking of the study. Uganda's agriculture being largely dependent on climatic variables such as rainfall and temperature, it also relies on other factors such as physical inputs like capital, land, labour among others. As a result, the overall agricultural values are dependent on these factors.

The estimation model specification appears as:

$Y_{i j}=f\left(Z_{i j}, C\right)+u_{i j}$,

The relationship specified in equation 1 is the original Ricardian reduced form of Mendelsohn et al. (1994) with land values as the dependent variable. Where $Y_{i j}$ is the land value for household $i$, planting crop $\mathrm{j}, \mathrm{Z}$ is the vector of input variables. $C$ represents a set of exogenous environmental factors such as temperature, precipitation and a set of geographic factors such as soil characteristics. $u_{i j}$-error term assumes a normal distribution with zero mean and constant variance. The assumption is that climate, socio-economic and soil factors influence the land values (Y). Empirically, authors have variously defined the dependent variable, $Y_{i j}$. In some studies of Lippert et al. (2009), Mendelsohn et al. (2010), Massetti \& Mendelsohn (2011) and Fezzi \& Bateman (2012) express it as land price, while others like Kurukulasuriya \& Mendelsohn (2008),Wang et al. (2008) and Salvo et al. (2014) express it as net farm revenue. Lastly, Schlenker \& Roberts (2008) and Rowhani et al. (2011) use agricultural output. Indeed, the economic theory gives little guidance on the nature of the functional form (Fezzi \& Bateman, 2012) and as such, several studies that have used it, based on the nature of research questions and data availability. Fezzi \& Bateman (2012) affirm that modellers have transformed equation (1) into empirically tractable model assuming a linear or semi-log specification with a quadratic or linear formulation for the climatic variables and a linear functional form for all other determinants.

Fezzi \& Bateman (2012) further recommend the use of smoothing function but, Salvo et al. (2014) caution that the use of modelling data without imposing a specific functional form is limited to continuous variables. Due to unavailability of data, control variables are frequently expressed using dummy/categorical variables for which it is not possible to use smoothing function. Model (1) was re-defined in terms of panel data model and the variables that are changing overtime were indexed with subscript $t$ while following Deschenes \& Greenstoe (2006) specicification as;

$\boldsymbol{Y}_{i t}=\dot{a}_{i}+\boldsymbol{X}_{i t}^{\prime} \hat{\boldsymbol{a}}+\sum_{d} \tilde{a}_{d} f_{d}\left(C_{d t}\right)+\boldsymbol{u}_{i t}$

Where $Y$, is agricultural farm values of crop $i$ at time t. $X_{i t}$ is a vector comprising of the factors that influence output production, $C_{d t}$ is climate variable. $a_{i}$ is a set of fixed effects, $\hat{a}$ is the vector coefficient of non-climate factors. The coefficient vector $\tilde{\boldsymbol{a}}_{d}$ represents the effect of climate change on the agricultural production. The effect of climate change in this model is a linear function of the parts of the $\tilde{\boldsymbol{a}}_{d}$ vector. $\mathrm{u}_{\mathrm{it}}$ is the error term. The unique nature of the agricultural sector largely makes it susceptible to a variety of negative shocks such as pests, disease epidemics, drought, floods, and hailstorms among others. These shocks adversely lower agricultural production levels to nothingness. The nature of agricultural shocks causes agricultural returns (dependent variable) to assume dual possible values, nothingness (zeros) and positive values. Nothingness is the lower limit one can have. White (2007) says, "Nothing is absolutely the limit of nothingness". Tobin (1958) using a specific example observed that households reported zero expenditures on key household durable goods or automobiles in a given year. 
He advised that it is inefficient to do away with such information if the value of the dependent variable is not available. This resulted into the popularly known Tobit regression model. McDonald \& Moffitt (1980) supplement that the Tobit analysis assumes that the dependent variable has many numbers of its values clustered around limiting value, usually zero and provide an example of data on hours of work that are often clustered at zero. Splett et al. (1994) note that Tobit model is appropriate for conditions under which the dependent variable is observable for values over and above zero but latent for values at most zero. Calzolari et al. (2001) aver that due to the censoring or "missingness" in the data, the Tobit regression estimated parameters do not signify the decrease or increase in the value of the independent variables. The standard Tobit model specification follows:

$Y_{i t}^{*}=\boldsymbol{X}_{i t}^{/} \hat{\boldsymbol{a}}+\stackrel{\boldsymbol{a}}{i t}_{i t}$

With the assumption that $\stackrel{\circ}{a}_{i t} \sim N\left[0, \hat{o}_{u}^{2}\right]$, i.i.d. and independent from $X_{i t}, i=1, \ldots, N ; t=1, \ldots, T$ and we observe,

$Y_{i t}=\left\{\begin{array}{ccc}Y_{i t}^{*} & \text { if } & Y_{i t}^{*}>0 \\ 0 & \text { if } & Y_{i t}^{*} \leq 0 .\end{array}\right.$

$\stackrel{\circ}{\boldsymbol{a}}_{i t}=\dot{a}_{i}+\lambda_{t}+\boldsymbol{u}_{i t}$

Where $a_{i}$ is the individual effects and represents unobservable specific characteristics for individual $i$ and remains constant across time, the time effect is denoted by $\lambda_{t}$ and represents all unobservable characteristics of time at period $t$, and assumed to remain constant for all the cross-sectional units in the sample. While $u_{i t}$ is the stochastic error term that varies across individuals and time. In this study, $\lambda_{t}$ assumes zero values for all values of t. Hence, equation (3) of the standard Tobit panel specification following the Cameron \& Trivedi (2005) becomes:

$Y_{i t}^{*}=\hat{a}_{i}+\boldsymbol{X}_{i t}^{\prime} \hat{\boldsymbol{a}}+\boldsymbol{u}_{i t}$

Following the above explanations, the study uses equation 7, a result of modifying equations 2 and 6 .

$Y_{i t}^{*}=\dot{a}_{i}+X_{i t}^{\prime} \hat{a}+\dot{a}_{c} D+\sum_{d} \tilde{a}_{d} f_{d}\left(C_{d t}\right)+u_{i t}$

Where $X_{i t}^{\prime}$ is a continuous vector of non-climate factors such as capital, labour and farm size, D is a set of vectors, namely irrigation, use of fertilizers, flooding and soil quality while $C_{d t}$ represents climate factors such as rainfall and temperature.

Data, Study Area and Sampling: The study uses Uganda National Panel Survey (UNPS) datasets of 2009/10(wave1), 2010/2011(wave II), 2011/2012(wave III) and 2013/2014(wave IV) collected by Uganda Bureau of Statistics (UBOS). These data are part of the World Bank's Living Standards Measurement StudyIntegrated Surveys on Agriculture (LSMS-ISA) undertaken in some African countries, such as Uganda, Ghana, South Africa inter aralia. The UNPS conducted throughout the country covered five modules, namely price, woman, socio-economic, community and agriculture. Specifically, the agriculture module questionnaire covered the subset of UNPS households engrossed in agricultural activities such as crop and livestock production. The agricultural module captures data on various aspects such as data on current land holdings and household land user rights, agricultural inputs (capital, labour, and fertilizers), crops grown among others. In other words, the module permits the land area estimation, both owned and cultivated, as well as production quantification for major crops inter alia. It also allowed collection of information on irrigation, flooding and access to extension services.

In each wave, the sampled household was visited twice per year to cover two agricultural cropping seasons. The first season refers to the cropping cycle of temporary crops that are grown and reaped at the end of the second quarter of the year, usually stretching to the end of June. It therefore covers the months ranging from January to June. While the second cropping season usually runs from September to December. The seasons directly coincide with the rains as well as the growing cycle of crops (UBOS, 2009a). The questionnaires administered to each household were similar for each wave with little or no modifications. Due to two cropping seasons per year, two other sub-waves resulted for each year, making it eight sub-waves in total. By end June of 2008, the numbers of districts were eighty in Uganda (UBOS, 2009b). The first wave (2009/10 UNPS) collection exercise began from September of 2009 to August of 2010 and covered all the 80 districts as of 2009. The random selection comprised of 2,975 households across the country, indicating that LSMS survey was nationally representative. The 2009/10 UNPS covered 2,975 households stretching over 322 Enumeration Areas (EAs) in the four regions of Central, Eastern, Northern and Western. 
The 2010/11 UNPS sampled 2,716 households. The 2011/12 UNPS covered 2,346 households. Comparing the waves, we notice attrition of households. World Bank (2011) reveals that incidences of death, migration, imprisonment or hiding from creditors among others create attrition problems faced in panel surveys. While the 2013/14 UNPS involved refreshing a third of the sample of the first wave that had 2,975 households. UBOS (2015) posits that the approach of refreshing the sample does offset the loss of representativeness, since the new households have equal probability of selection. Baltagi (2008) instead calls the refreshing sample, a rotating panel. The preceding paragraphs provide a clear argument why the study opted for the unbalanced panel data despite the problems of attrition and selection biases. The crops for analysis used in the study include fruits, such as bananas; cereals such as maize; oil seeds such as, groundnuts; root tubers such as cassava and leguminous crops such as beans. These crops were selected for the study because Caffrey et al. (2013) cite them as the most affected by the vagaries of climate change in Uganda. Secondly, these crops were the major crops grown by almost every household countrywide (UBOS, 2013).

Climate data specifically for precipitation and temperature were obtained from Uganda National Meteorological Authority (UNMA). The climate data was from 13 weather stations, which include Entebbe, Makerere-Kampala, Soroti, Kasese, Namulonge, Gulu, Lira, Mbarara, Kabale, Masindi, Kitgum, Arua and Jinja. The UNMA precipitation and temperature data of each district was either incomplete or missing. Global weather data for SWAT was found to be complete and fully available for each district. The data was downloaded from the website www.globalweather.tamu.edu for Uganda from 1979 to 2014 covering 417 weather stations. Despite the presence of climate data over a long period, the study utilized only climate data that corresponded with the four waves only. Using Google maps, latitude and longitude coordinates for each district were mapped to global weather data. It aimed at attaining all temperature and rainfall data for each district that prevailed during agricultural production periods. The average monthly climate data was combined with agricultural data to form one complete data set for analysis.

Table 1: Variable Description and Expected Signs

\begin{tabular}{|c|c|c|}
\hline Variable & Description & Expected Sign \\
\hline $\begin{array}{l}\text { Agricultural farm } \\
\text { returns }\end{array}$ & Estimate of the market value of output in dollars per household & $\begin{array}{l}\text { Dependent } \\
\text { variable }\end{array}$ \\
\hline Labour & $\begin{array}{l}\text { Labour was computed as person days. Person Days represent labour } \\
\text { input. Person Days=Number of days worked *Number of workers. }\end{array}$ & + \\
\hline Capital & $\begin{array}{l}\text { Total amount of capital expressed in US \$. Capital valuation involved } \\
\text { aggregation of the cost of hand hoes, ploughs, pangas, harrows, } \\
\text { wheelbarrows, slashers, planter, pruning saws, knives, watering cans, } \\
\text { sprayer, sheller, wheeler, planter, tractor and spades; }\end{array}$ & + \\
\hline Farm size & Plot/farm size, expressed in acres. & + \\
\hline Fertilizers. & $\begin{array}{l}\text { It is a dummy variable, } 1 \text { if a household used fertilizers and zero, } \\
\text { otherwise. }\end{array}$ & + \\
\hline Soil Quality & $\begin{array}{l}\text { It is a dummy variable, } 1 \text { if a respondent perceived soil quality as } \\
\text { good/fair and } 0 \text { otherwise. }\end{array}$ & + \\
\hline Irrigation & $\begin{array}{l}\text { A dummy variable, } 1 \text { if a household practised irrigation and } 0 \\
\text { otherwise. }\end{array}$ & + \\
\hline Flooding & $\begin{array}{l}\text { A dummy variable, } 1 \text { if a particular household experienced flooding in } \\
\text { a given cropping season and } 0 \text { otherwise. }\end{array}$ & - \\
\hline Temperature & $\begin{array}{l}\text { Monthly average temperature in degrees Celsius as units of } \\
\text { measurement. }\end{array}$ & - \\
\hline Rainfall & Monthly average rainfall, expressed in millimeters. & + \\
\hline
\end{tabular}
Source: Authors' own

\section{Results and Discussion}

Agricultural farm returns are expressed in dollars with threshold value appearing as zero for various periods farmers harvested and this demotivates farmers from undertaking agricultural activities that are largely prone to losses. We note that the reasons for the pre-harvest loss in crop agro-based households were drought, floods, animals, pests, and hailstorms as shown in Table 2. 
Table 2: The Main Reasons for the Pre-Harvest Loss per Crop

\begin{tabular}{llllllllll}
\hline Crop & Drought & Floods & Animals & Pests & Hailstorms & Others & Tot & Observations & \%gee \\
\hline Banana & 11 & 1 & 5 & 10 & 3 & 20 & 50 & 2550 & 1.96 \\
Maize & 208 & 28 & 36 & 14 & 9 & 30 & 325 & 4487 & 7.24 \\
G/ nuts & 93 & 12 & 12 & 7 & 2 & 6 & 132 & 1787 & 7.39 \\
Cassava & 58 & 19 & 19 & 20 & 3 & 85 & 204 & 2638 & 7.73 \\
Beans & 164 & 29 & 7 & 15 & 10 & 34 & 259 & 4534 & 5.71 \\
Total & 534 & 89 & 79 & 66 & 27 & 175 & 970 & 15996 & \\
\hline
\end{tabular}

Source: Author's calculations based on UNPS data

Table 2 shows that most households cited drought and floods as some of the major challenges affecting agricultural returns. The climate related disasters such as drought, floods and hailstorms accounted for over 67 percent of the factors affecting agricultural returns. The worst adversely affected crops were maize, beans and groundnuts. The main reason why most agricultural households experience large amounts of pre-harvest losses is due to overdependence on rain-fed agriculture as shown in Table 3, which shows water sources for agricultural production. Rains fall unexpectedly, for example, rains may appear early before gardens are prepared for planting and in some instances, rains stop when crops are starting to flower. Agricultural households with limited means to adapt irrigation watch their crops wither during dry spells. Various reasons explain why households fail to undertake adaptive strategies among which include low household incomes, limited sensitization of farmers, and lack of water tank reservoirs to store water that could be used during dry spells. Government's sloppiness to provide the high cost irrigation infrastructure worsens the situation. Largely, these factors leave agricultural households without any other practical options; hence despairingly depend on natural rains instead of irrigation as shown in Table 3.

Table 3: Water Sources for Farming

\begin{tabular}{llll}
\hline Crop & Source & Frequency & Percentage \\
\hline \multirow{2}{*}{ Banana } & Rain-fed & 2510 & 98.4 \\
& Irrigated & 40 & 1.57 \\
Maize & Rain-fed & 4405 & 98.17 \\
& Irrigated & 82 & 1.83 \\
G/nuts & Rain-fed & 1758 & 98.38 \\
& Irrigated & 29 & 1.62 \\
Cassava & Rain-fed & 2583 & 97.92 \\
& Irrigated & 55 & 2.08 \\
Beans & Rain-fed & 4457 & 98.3 \\
& Irrigated & 77 & 1.7 \\
\hline
\end{tabular}

Source: Authors' calculations based on UNPS data

Table 3 shows that on average, over 98.24 percent of the agricultural households entirely rely on the rain-fed agriculture. The percentage of households that irrigated on average was 1.76 percent. Amidst these climate shocks such as rainfall deficits, farmers without adaptive and cushioning strategies like irrigation are more food insecure, famine-prone, hunger stricken and subject to welfare loss and lower standards of living. In addition to the large agricultural losses emanating from long drought spells, prevalent floods at the end of dry hexes together with heavy destructive rains characterized by gales and hailstorms magnify the losses. The flooding incidences are repetitive in nature across the country. Agricultural households located on mountain slopes experience repetitive mudslides. Apart from being destructive to agricultural production, at worst, people lose their lives to mudslides that heap over their homesteads. The coefficients of labour input were positive and statistically significant for regressions of banana and beans. Households have stayed continuously in mudslide-prone areas due to scarcity of land favourable for extensive farming. As a result, land wrangles and conflicts are common in the country. 
Regressions: The dependent variable has some zero values for each crop, the Tobit model was appropriate (Tobin, 1958). Panel Tobit and Pooled Tobit regression estimates appear in Table 4 and all continuous variables are in logarithmic form. The regression coefficients of capital, labour, farm size, temperature and rainfall represent elasticities, while soil quality, irrigation, fertilizers and flooding are dummies. The Pooled Tobit coefficient estimates are matching in sign with those of the panel Tobit model, and the statistical significance of all regression estimates are found similar except for the coefficient of flooding in the regression of banana. Basing on the Akaike (1973) Information Criterion (AIC) and Schwarz (1978) Bayesian Information Criterion (BIC), all the interpretations are based on the Tobit panel regression results. The next discussion is for the results presented in Table 4.

Table 4: Panel Tobit and Pooled Tobit Regression Estimates

\begin{tabular}{|c|c|c|c|c|c|c|c|c|c|c|}
\hline \multirow[b]{2}{*}{ Variables } & \multicolumn{2}{|l|}{ Banana } & \multicolumn{2}{|l|}{ Beans } & \multicolumn{2}{|l|}{ Cassava } & \multicolumn{2}{|l|}{ G/nuts } & \multicolumn{2}{|l|}{ Maize } \\
\hline & Panel & Pooled & Panel & Pooled & Panel & Pooled & Panel & Pooled & Panel & Pooled \\
\hline \multirow[t]{2}{*}{ Capital } & $0.137^{* * *}$ & $0.144^{* * *}$ & $0.195^{* * *}$ & $0.199 * * *$ & 0.042 & 0.042 & $0.203^{* * *}$ & $0.189^{* * *}$ & $0.176^{* * *}$ & $0.185^{* * *}$ \\
\hline & $(0.023)$ & $(0.025)$ & $(0.017)$ & $(0.018)$ & $(0.028)$ & $(0.028)$ & $(0.03)$ & $(0.031)$ & $(0.016)$ & $(0.017)$ \\
\hline \multirow[t]{2}{*}{ Labour } & $0.050^{* *}$ & $0.052^{* *}$ & $0.043^{* *}$ & $0.045^{* * *}$ & $-0.12^{* * *}$ & $-0.12^{* * *}$ & -0.02 & -0.026 & $-0.12^{* * *}$ & $-0.117^{* * *}$ \\
\hline & $(-.021)$ & $(0.021)$ & $(0.017)$ & $(0.017)$ & $(0.024)$ & $(0.023)$ & $(0.029)$ & $(0.03)$ & $(0.02)$ & $(0.021)$ \\
\hline \multirow[t]{2}{*}{ Farmsize } & $0.206^{* * *}$ & $0.226^{* * *}$ & 0.032 & 0.032 & $0.086^{* * *}$ & $0.086^{* * *}$ & $0.087^{* * *}$ & $0.109^{* * *}$ & $0.116^{* * *}$ & $0.122^{* * *}$ \\
\hline & $(0.024)$ & $(0.026)$ & $(0.02)$ & $(0.02)$ & $(0.025)$ & $(0.027)$ & $(0.033)$ & $(0.035)$ & $(0.02)$ & $(0.021)$ \\
\hline \multirow[t]{2}{*}{ Fertilizers } & $0.131^{*}$ & $0.148^{* *}$ & -0.033 & -0.018 & $0.239 * * *$ & $0.239 * * *$ & 0.065 & -0.032 & $-0.46^{* * *}$ & $-0.469^{* * *}$ \\
\hline & $(0.07)$ & $(0.067)$ & $(0.061)$ & $(0.054)$ & $(0.055)$ & $(0.053)$ & $(0.119)$ & (0.109) & $(0.078)$ & $(0.064)$ \\
\hline \multirow[t]{2}{*}{ S/Quality } & 0.001 & -0.036 & $-0.16^{* * *}$ & $-0.156^{* *}$ & & 0.029 & $0.365^{* * *}$ & $0.312^{* * *}$ & $0.351^{* * *}$ & $0.356^{* * *}$ \\
\hline & $(0.104)$ & (0.109) & $(0.055)$ & $(0.063)$ & $(0.078)$ & $(0.085)$ & $(0.101)$ & $(0.11)$ & $(0.061)$ & $(0.064)$ \\
\hline \multirow[t]{2}{*}{ Irrigation } & 0.084 & 0.11 & 0.107 & 0.094 & -0.161 & -0.161 & 0.359 & $0.338^{* *}$ & 0.038 & 0.038 \\
\hline & $(0.188)$ & $(0.182)$ & $(0.137)$ & (0.157) & $(0.182)$ & (0.193) & $(0.238)$ & $(0.164)$ & $(0.152)$ & $(0.144)$ \\
\hline \multirow[t]{2}{*}{ Flooding } & -0.128 & $-0.159 *$ & -0.074 & -0.076 & -0.019 & -0.019 & $-0.195^{*}$ & $-0.175^{*}$ & $-0.24^{* * *}$ & $-0.270^{* * *}$ \\
\hline & $(0.091)$ & $(0.094)$ & $(0.064)$ & $(0.068)$ & $(0.087)$ & $(0.092)$ & $(0.1)$ & $(0.104)$ & $(0.064)$ & $(0.07)$ \\
\hline \multirow[t]{2}{*}{ Temp } & $-1.700^{* * *}$ & $-1.86^{* * *}$ & $-1.01^{* * *}$ & $-0.97 * * *$ & $-1.5^{* * *}$ & $-1.50^{* * *}$ & $0.543^{* * *}$ & $-1.26^{* * *}$ & $-2.02^{* * *}$ & $-2.005^{* * *}$ \\
\hline & $(0.304)$ & $(0.301)$ & $(0.197)$ & $(0.206)$ & $(0.309)$ & $(0.309)$ & $(0.063)$ & $(0.32)$ & $(0.238)$ & $(0.221)$ \\
\hline \multirow[t]{2}{*}{$\mathrm{R} / \mathrm{F}$} & -0.02 & -0.03 & $-0.08^{* * *}$ & $-0.08^{* * *}$ & -0.035 & -0.035 & $0.115^{* * *}$ & 0.032 & -0.025 & -0.026 \\
\hline & $(0.025)$ & $(0.026)$ & $(0.018)$ & $(0.017)$ & $(0.027)$ & $(0.027)$ & $(0.024)$ & $(0.029)$ & $(0.02)$ & $(0.02)$ \\
\hline \multirow[t]{2}{*}{ Sigma_u } & $0.445^{* * *}$ & $1.191^{* * *}$ & $0.267^{* * *}$ & $1.180^{* * *}$ & 0 & $1.308^{* * *}$ & $0.338^{* * *}$ & $1.251^{* * *}$ & $0.424^{* * *}$ & $1.348^{* * *}$ \\
\hline & $(0.044)$ & $(0.021)$ & $(0.046)$ & $(0.017)$ & $(0.118)$ & $(0.025)$ & $(0.087)$ & $(0.029)$ & $(0.04)$ & $(0.019)$ \\
\hline \multirow[t]{2}{*}{ Sigma_e } & $1.106^{* * *}$ & & $1.150^{* * *}$ & & $1.308^{* * *}$ & & $1.216^{* * *}$ & & $1.280^{* * *}$ & \\
\hline & $(0.021)$ & & $(0.016)$ & & $(0.019)$ & & $(0.031)$ & & $(0.018)$ & \\
\hline AIC & 8119.65 & 8234.7 & 14310.1 & 14318 & 8794.51 & 8792 & 5804.27 & 5806.38 & 15222.2 & 15263.5 \\
\hline BIC & 8189.77 & 8234.7 & 14380.6 & 14382.6 & 8859 & 8851.22 & 5864.53 & 5861.17 & 15292.6 & 15327.5 \\
\hline Wald chi2 & $206.14^{* * *}$ & & $19203^{* * *}$ & & $10760.51 *$ & ** & $7791.00^{* *}$ & & $14531.85^{\prime}$ & ** \\
\hline $\mathrm{F}$ & & $2333.15^{* *}$ & & $2494.19^{* *}$ & & $1264.77^{* *}$ & & 960.58 & & 2058.16 \\
\hline $\mathrm{N}$ & 2,549 & 2,549 & 4,516 & 4,516 & 2,621 & 2,621 & 1,769 & 1,769 & 4,469 & 4,469 \\
\hline $\mathrm{N}$ & 1,207 & & 1,860 & & 1,510 & & 1,017 & & 1,936 & \\
\hline Robust & standard & errors & in & parenth & eses & $* *$ & 0.01 & $* *$ & 0.05 & \\
\hline
\end{tabular}

The results indicate that the coefficients of capital have the expected positive sign and are significantly different from zero at one percent level of significance, for crops such as banana, beans, groundnuts and maize. In the same vein of research, Odhiambo et al. (2004) and, Raza \& Siddiqui (2014) identify physical capital as a major determinant of agricultural farm returns. The results affirm a fact that capital remains a vital input for agricultural production as it greatly affects agricultural returns or farm revenues. Ajwad et al. (2004) in the same steps affirm that at the household level, over a half of the changes in the agricultural revenues are explained by non-climate factors such as physical capital available to farmers as well as capacity to adapt it at the farm level. Despite agricultural physical capital's importance, limited affordability, 
accessibility and low absorption of improved technology remain major challenge to farmers in Uganda according to UBOS (2013). Labour is another vital input for agricultural production. The output elasticities with respect to labour are 0.05 for beans and 0.04 for banana. The positive coefficient validates a fact of great importance of labour input in the production process. In contrast, the coefficients of labour input in the regressions of cassava and maize are statistically significant and negative. These output elasticities with respect to labour input for Uganda are the lowest compared to other countries such as Japan, 0.26 for rice; 0.59 for vegetables and potatoes (see Tokunaga et al., 2015) and Fezzi \& Bateman (2015) obtained 3.751 for United Kingdom.

The difference in output elasticities due to labour is not surprising since labour is highly skilled unlike in Uganda where majority of workers are unskilled. Secondly, the sector employs labour force rejects from other sectors. UBOS (2013) posits that agricultural sector absorbs the biggest percentage of the labour force left out by other various sectors of the economy yet it absorbs 32 percent of the total labour force. Deductively, one could allude that these are the majority-disgruntled workers. However, the sample of 88 observations used in the study of Tokunaga et al. (2015) was small; we are of the view that with a larger sample, the elasticities could have looked different. The elasticities due to labour input for cassava and maize are -0.120 and -0.123 , respectively, however, groundnuts had negative coefficient but not significant. In the same line, KabuboMariara \& Kabara (2018) using population density to represent availability of farm labour, find elasticity for beans as 0.00001 . They also found that maize elasticity was positive but not significant. The sign of coefficient of labour is a mixed bag since labour can be associated with both low and high agricultural returns or output because of the law of diminishing returns (Shephard, 1970). The farm size coefficients are positive and significant for almost all crop regressions under study, explicitly: banana, cassava, groundnuts and maize, although the farm size coefficient for beans was not significant. The output elasticities due to farm size are 0.206 for banana, 0.086 for cassava, 0.087 for groundnuts and 0.116 for maize.

These elasticities are not different from what Tokunaga et al. (2015) got in Japan, for example 0.16 for rice. The results indicate that acquisition of more land acreage increases agricultural returns in Uganda. Most farmers in Uganda are smallholder farmers cultivating less than one hectare of land, with probability of increasing up to 10 hectares in the less populated semi-arid zones (Salami et al., 2010). Acquiring more land with intention of expanding agricultural activities remains a mirage due to high population densities. UBOS (2013) advises that, despite scarcity of land, hope is not entirely lost, with appropriate use of inputs and adoption of improved farming methods, the quality and quantity of agricultural yields can increase with the same plots of land. Farmers that applied fertilizers significantly had more farm returns in particular for banana, and cassava growers. According to UBOS (2010) organic fertilizers are widely used by farmers in Uganda. These include green manure, farmyard compost and seaweed. Farmyard manure is made of mixture of cow dung, urine and litter, mostly straw that often absorbs urine. The findings are in agreement with the Mall et al. (2006) who find that farmers applying fertilizers obtain the same harvest; they were getting without fertilizers 20 to 30 years ago. Inferably, tilling land for long, exhausts the soil fertility hence need for use of fertilizer to increase farm values. Further, Mall et al. (2006) contend that changes in both temperature and precipitation are having greater effects on run-off and soil erosion, biodiversity, salinization and soil water content, all of which are impactful in dissolving nutrients in the soil. All these have greater impact on soil fertility hence the need for continued application of fertilizers. This replenishes soil fertility if correctly applied with appropriate soil tests for salinity and alkalinity.

In contrast, maize growers significantly earned less farm returns. Application of fertilizers had no effect on farm returns for farmers that grew beans. Usually, smallholder farmers are often reluctant to apply fertilizers since leguminous crops such as beans and peas regularly fix their nitrogen in the soil. Sharma et al. (2014) establish that continued application of imbalanced inorganic fertilizers culminated into lesser crop yields of wheat and maize as it increases carbon soil content and decreases PH. Chang et al. (2014) and Han et al. (2016) caution that using inorganic fertilizers over a continuous longer period is more harmful than organic fertilizers derived from sawdust and livestock products such as cow dung. Further, application of inorganic or chemical fertilizers demands soil tests. Findings reveal that farmers that applied fertilizers were significantly not different from those that did not in terms of farm returns. We find this revelation not surprising since the farmers scarcely apply fertilizers in their gardens. GoU (2016) documents that farmers add only between 1$1.5 \mathrm{~kg}$ of nutrients for each hectare per annum, for every estimated loss of $80 \mathrm{~kg}$, hence positioning Uganda as 
the least country in fertilizer usage across the globe and also this rate of usage is below the mean of $8 \mathrm{~kg}$ per hectare in SSA. As a result, GoU (2016) attributes soil infertility and limited agricultural growth to limited use of fertilizers. The coefficients of soil quality are positive and significant for both regressions of groundnuts and maize. Farmers whose soils were good had more farm returns than their counterparts did. KabuboMariara \& Kabara (2018) identify soils as good if they can keep enough moisture to support plant growth. However, growers of beans whose soils were good earned less revenues. They also find that silt soils were negatively associated with farm returns.

On the other hand, the soil quality had no significant effect on farm returns for banana and cassava growers. GoU (2016) report shows that smallholder farmers can detect the soil quality as bad by perception and not scientifically. This is attributed to several reasons. First, they lack knowledge and capacity to test the nitrogen, phosphorous and potassium (NPK) ratio of the farm soils in the laboratory. Second, majority of farmers are short of knowledge and capacity to restock the missing soil nutrients, while others have a myth that fertilizers spoil soils. Irrigation had no any significant effect on farm values for farmers that grew banana, beans, maize, and cassava. It is not strange to find that irrigation has no impact on farm returns since the number of farmers that irrigated was less than 1 percent of the total respondents. UBOS (2013) documents that less than 1 percent of the land in Uganda is irrigated and the agricultural production is widely rain-fed. UBOS (2013) further reports that irrigation remains the best option to address the unpredictable weather variations, however, lack of affordability arising from high outlay needed to install irrigation infrastructure, keeps the venture as a distant dream. The effect of unreliable rainfall patterns and drought are ubiquitous. The high dependence on rain-fed agriculture impedes agricultural production (GoU, 2017). The proportion of agricultural households that practised irrigation in 2009/10 was one percent while in 2010/11 it was three percent. Bacha et al. (2011) cite smallholder irrigation as a pillar for attaining improved agricultural production, food security and lower rural poverty levels. Flooding had a significant negative relationship with farm returns for crop regressions of groundnuts and maize.

Climatic Variables: The coefficients of temperature are negative and statistically significant for banana, beans, cassava, and maize. The output elasticities with respect to temperature lie between -2.02 percent and 0.543 percent. This implies that for the average temperature increase by 1 percent, cassava farm returns decrease by 1.50 percent and beans by 1.004 percent. We notice that cassava and beans were the most hit crops by rising temperatures. These empirical results are consistent with those of Tokunaga et al. (2015) in Japan whose elasticities are between -0.39 percent and -0.82 percent. Etwire et al. (2019) in Ghana find that for 1 percent increase in average temperature, the plantains revenues decrease by 2.612 percent, in Nigeria, Ater \& Aye (2012) empirically estimate elasticity as -2.589 percent. Exenberger et al. (2014) find different elasticities for grouped countries, for example -0.004 percent for high income, -0.014 percent for middle income and -0.016 percent for low income. The difference in response to climate changes is responsible for a big output gap in agriculture between SSA and the developed countries (Barrios et al., 2008). These empirical results approve a mantra that SSA suffers more numerous adverse effects of climate change, yet it emits little greenhouse gases (Appiah, 2017). In contrast, temperature is positive and statistically significant for groundnuts. The results indicate that when average temperature increases by 1 percent, on average groundnuts' farm revenues increase by 0.543 percent. Other studies also find a significant effect of average temperature on farm revenues, for example Etwire et al. (2019) in Ghana establish that when average temperature increases by 1 percent, on average maize farm revenues increase by 0.28 percent. In addition, farmers of beans and cassava had fewer returns due to flooding although the effect was not significant.

This finding is in agreement with Bezabih et al. (2014) who find that floods were majorly responsible for low levels of output and famine in Ethiopia. In Kenya, Kabubo-Mariara \& Kabara (2018) delineate how water logging and flooding destroy crops in the formative stages, while rotting of mature crops occurs during harvest season. We deductively assert that most of flood-prone areas are wetlands. Largely, flooding is due to anthropogenic actions that have encroached on wetlands and swampy areas for cultivation. The coefficient of average precipitation was positive and statistically significant for groundnuts. When the average precipitation increases by 1 percent, the groundnuts' farm returns increase by 0.115 percent. In the same vein of research, Granados et al. (2017) and Ater \& Aye (2012) obtain similar results. On the contrary, average, precipitation has a significant negative relationship with farm returns for beans. These results are in agreement with the findings of Tokunaga et al. (2015) and Nyuor et al. (2016). When average precipitation 
increases by 1 percent, the beans farm returns decrease by 0.077 percent. The rains are destructive, often characterized by hailstorms, strong winds, flooding, and mudslides. Mudslides and floods are so rampant in the eastern parts of the country. Rainfall has no significant effect on farm returns for banana, cassava and maize. Attrition is a common problem with panel data that cannot be ignored. Using the Heckit model, the attrition bias test results appear in Table 5. There is no evidence for attrition bias for regressions of banana and beans. In contrast, the bias was found existent for cassava, groundnuts and maize regressions. In summary, the farm value elasticities imputed to temperature are far greater in magnitudes compared to those of rainfall, an indication that rising average temperatures and rainfall deficits adversely cause greater reductions in farm returns of agricultural households in Uganda.

Table 5: Attrition Test Results

\begin{tabular}{llllll}
\hline Variables & Banana & Beans & Cassava & G/nuts & Maize \\
\hline Capital & $0.135^{* * *}$ & $0.152^{* * *}$ & -0.024 & $0.110^{* * *}$ & $0.120^{* * *}$ \\
& $(0.028)$ & $(0.032)$ & $(0.03)$ & $(0.039)$ & $(0.027)$ \\
Labour & $0.051^{* *}$ & $0.057^{* * *}$ & $-0.09^{* * *}$ & -0.023 & $-0.072^{* *}$ \\
& $(0.021)$ & $(0.018)$ & $(0.024)$ & $(0.029)$ & $(0.03)$ \\
Farmsize & $0.218^{* * *}$ & $0.042^{*}$ & 0.028 & $0.104^{* * *}$ & $0.115^{* * *}$ \\
& $(0.032)$ & $(0.022)$ & $(0.026)$ & $(0.033)$ & $(0.021)$ \\
Flooding & -0.136 & -0.047 & 0.12 & 0.029 & -0.089 \\
& $(0.093)$ & $(0.066)$ & $(0.089)$ & $(0.115)$ & $(0.082)$ \\
Temperature & $1.839^{* * *}$ & -0.461 & -0.351 & 0.762 & $1.274^{* * *}$ \\
& $(0.388)$ & $(0.375)$ & $(0.368)$ & $(0.694)$ & $(0.316)$ \\
Rainfall & -0.022 & $-0.042^{*}$ & 0.006 & 0.023 & -0.023 \\
& $(0.024)$ & $(0.023)$ & $(0.027)$ & $(0.027)$ & $(0.02)$ \\
Biasterm & 0.357 & -1.033 & $-2.90^{* * *}$ & $-2.98^{* * *}$ & $-2.29^{* * *}$ \\
& $(1.343)$ & $(0.708)$ & $(0.443)$ & $(0.825)$ & $(0.656)$ \\
Irrigation & ..a & 0.207 & -0.262 & $n . a$ & -0.221 \\
& $\mathrm{n} . \mathrm{a}$ & $(0.142)$ & $(0.18)$ & $n . \mathrm{a}$ & $(0.166)$ \\
Constant & $8.863^{* * *}$ & $3.878^{* * *}$ & $4.653^{* * *}$ & 0.688 & $7.374^{* * *}$ \\
\multirow{2}{*}{ Sigma_u } & $(1.199)$ & $(1.135)$ & $(1.201)$ & $(2.082)$ & $(0.987)$ \\
& $0.439^{* * *}$ & $0.262^{* * *}$ & 0 & $0.359^{* * *}$ & $0.425^{* * *}$ \\
Sigma_e & $(0.045)$ & $(0.047)$ & $(0.116)$ & $(0.081)$ & $(0.045)$ \\
& $1.111^{* * *}$ & $1.152^{* * *}$ & $1.303^{* * *}$ & $1.204^{* * *}$ & $1.311^{* * *}$ \\
$\mathrm{~N}$ & $(0.022)$ & $(0.016)$ & $(0.019)$ & $(0.031)$ & $(0.02)$ \\
$\mathrm{N}$ & 2,509 & 4,516 & 2,621 & 1,740 & 4,144 \\
\hline & 1,202 & 1,860 & 1,510 & 1,008 & 1,904 \\
\hline
\end{tabular}

Robust Standard errors in parentheses ${ }^{* * *} \mathrm{p}<0.01,{ }^{* *} \mathrm{p}<0.05,{ }^{*} \mathrm{p}<0.1$

Regional Analysis Using Different Geographic Areas: In Table 6, we present regional regression results of Central, Eastern, Northern and Western. Different regions have differing social and economic backgrounds, different conditions for crop farming, and ecological environments such as rainfall, temperature, soil types, vegetation, water and topography. Because of these differences, it is relevant to analyse results regionally. Central is the reference category. Despite the regular occurrence of floods in the eastern region, mudslides/landslides in the hilly and mountainous areas of Elgon have not only tremendously discouraged farming but also decreased farm returns (GoU, 2013). This clearly explains why increases in rainfall amounts significantly lower farm returns for households that cultivated beans and groundnuts in the eastern region. 
Table 6: Regression Coefficients with Regional Dummies

\begin{tabular}{|c|c|c|c|c|c|}
\hline Variables & Banana & Beans & Cassava & G/Nuts & Maize \\
\hline \multirow[t]{2}{*}{ Capital } & $0.136^{* * *}$ & $0.177^{* * *}$ & $0.052^{*}$ & $0.187^{* * *}$ & $0.138^{* * *}$ \\
\hline & $(0.023)$ & $(0.017)$ & $(0.028)$ & $(0.03)$ & $(0.016)$ \\
\hline \multirow[t]{2}{*}{ Labour } & 0.018 & $0.033^{* *}$ & $-0.11^{* * *}$ & -0.032 & $-0.14 * * *$ \\
\hline & $(0.021)$ & $(0.017)$ & $(0.024)$ & $(0.028)$ & $(0.020)$ \\
\hline \multirow[t]{2}{*}{ Farmsize } & $0.175^{* * *}$ & $0.057^{* * *}$ & $0.068^{* * *}$ & $0.098^{* * *}$ & $0.148^{* * *}$ \\
\hline & $(0.023)$ & $(0.020)$ & $(0.026)$ & $(0.033)$ & $(0.020)$ \\
\hline \multirow[t]{2}{*}{ Fertilizers } & 0.087 & -0.087 & $0.260^{* * *}$ & -0.047 & $-0.44^{* * *}$ \\
\hline & $(0.069)$ & $(0.062)$ & $(0.055)$ & $(0.120)$ & $(0.077)$ \\
\hline \multirow[t]{2}{*}{ Soil Quality } & 0.011 & $-0.118^{* *}$ & -0.03 & $0.311^{* * *}$ & $0.376^{* * *}$ \\
\hline & $(0.102)$ & $(0.055)$ & $(0.079)$ & $(0.101)$ & $(0.061)$ \\
\hline \multirow[t]{2}{*}{ Irrigation } & 0.045 & 0.042 & -0.085 & 0.324 & -0.072 \\
\hline & $(0.185)$ & $(0.137)$ & $(0.183)$ & $(0.236)$ & $(0.150)$ \\
\hline \multirow[t]{2}{*}{ Flooding } & -0.091 & -0.067 & -0.008 & -0.16 & $-0.17^{* * *}$ \\
\hline & $(0.089)$ & $(0.064)$ & $(0.087)$ & $(0.100)$ & $(0.064)$ \\
\hline \multirow[t]{2}{*}{ Temperature } & $-0.596^{*}$ & $-0.449 * *$ & $-1.74^{* * *}$ & $-1.32^{* * *}$ & $-1.16^{* * *}$ \\
\hline & $(0.315)$ & $(0.217)$ & $(0.336)$ & $(0.381)$ & $(0.253)$ \\
\hline \multirow[t]{2}{*}{ Precipitation } & 0.007 & $-0.06^{* * *}$ & -0.041 & 0.027 & -0.01 \\
\hline & $(0.023)$ & $(0.018)$ & $(0.027)$ & $(0.029)$ & $(0.020)$ \\
\hline \multirow[t]{2}{*}{ Eastern Dummy } & $-0.47^{* * *}$ & $-0.27^{* * *}$ & $0.182^{* *}$ & 0.076 & $-0.29 * * *$ \\
\hline & $(0.072)$ & $(0.056)$ & $(0.073)$ & $(0.103)$ & $(0.059)$ \\
\hline \multirow[t]{2}{*}{ Northern Dummy } & $-1.13^{* * *}$ & $-0.38 * * *$ & $0.282^{* * *}$ & -0.068 & $-0.67^{* * *}$ \\
\hline & $(0.133)$ & $(0.061)$ & $(0.080)$ & $(0.110)$ & $(0.067)$ \\
\hline \multirow[t]{2}{*}{ Western Dummy } & 0.064 & -0.066 & $0.217^{* * *}$ & 0.026 & $-0.133^{* *}$ \\
\hline & $(0.060)$ & $(0.049)$ & $(0.078)$ & $(0.100)$ & $(0.065)$ \\
\hline \multirow[t]{2}{*}{ Constant } & $5.107^{* * *}$ & $4.138^{* * *}$ & $8.502^{* * *}$ & $6.349^{* * *}$ & $7.284^{* * *}$ \\
\hline & $(1.026)$ & $(0.714)$ & $(1.110)$ & $(1.251)$ & $(0.826)$ \\
\hline \multirow[t]{2}{*}{ Sigma_u } & $0.378^{* * *}$ & $0.238^{* * *}$ & n.a & $0.365^{* * *}$ & $0.358^{* * *}$ \\
\hline & $(0.048)$ & $(0.050)$ & n.a & $(0.079)$ & $(0.045)$ \\
\hline \multirow[t]{2}{*}{ Sigma_e } & $1.100^{* * *}$ & $1.149^{* * *}$ & $1.304^{* * *}$ & $1.196^{* * *}$ & $1.280^{* * *}$ \\
\hline & $(0.021)$ & $(0.016)$ & $(0.010)$ & $(0.031)$ & $(0.018)$ \\
\hline $\mathrm{N}$ & 2,549 & 4,516 & 2,621 & 1,769 & 4,469 \\
\hline $\mathrm{N}$ & 1,207 & 1,860 & 1,510 & 1,017 & 1,936 \\
\hline
\end{tabular}

Robust standard errors in parentheses ${ }^{* * *} \mathrm{p}<0.01,{ }^{* *} \mathrm{p}<0.05,{ }^{*} \mathrm{p}<0.1$

The regional dummies in Table 6 show that both central and eastern regions reap more farm returns in the farming of bananas than northern region. The results also suggest that banana farm returns for western region are not different from those of central. Further, central and northern regions reap more farm returns from the farming of beans than other regions. Northern region gained more farm returns from the farming of both maize and cassava while the growing of groundnuts was mostly statistically significant in the central region as shown by the highest significant dummy coefficient. We also examined how climate factors affect farm returns regionally; beans growers experienced the worst effects of precipitation as shown by elasticity of -0.06 percent, while cassava growers were hit most by effects of temperature across the entire regions. Floods have more damaging effects on farm returns for both eastern and northern regions especially for maize growers. 


\section{Conclusion and Recommendations}

The paper examined the effect of both rainfall and temperature on agricultural returns. The climate related disasters such as drought, floods and hailstorms accounted for over 67 percent of the factors impeding agricultural returns and less than 2 percent of the farming households used irrigation. However, farmers that irrigated earned higher agricultural returns. The findings show that the output elasticities with respect to temperature range from -2.02 percent to 0.543 percent, while with respect to rainfall lie between -0.08 percent and 0.155 percent. The climate coefficients show that both root tubers and legumes are the most affected crops by climate changes. Further, temperature increases were more destructive than rainfall. Apart from climate factors, non-climate factors such as capital, labour, farm size, fertilizers and soil quality are equally important inputs and significantly affect agricultural farm returns.

Recommendations: Basing on the study findings, the study proposes that due to increasing adverse climate change effects in Uganda, adoption of multi-pronged approaches such as extensive irrigation, agro-based insurance, diversification of agricultural activities, use of food cribs during bumper harvests would lessen the effects of climate change.

Acknowledgements: We acknowledge the African Economic Research Consortium (AERC) and Kyambogo University Council for both material and financial assistance provided towards this paper.

\section{References}

Adams, R. M., Mccarl, B. A., Dudek, D. J. \& Glyer, J. D. (1988). Implications of Global Climate Change for Western Agriculture. Western Journal of Agricultural Economics, 13(2), 348-56.

Adams, R. M., Hurd, B. H., Lenhart, S. \& Leary, N. (1998). Effects of global climate change on agriculture:an interpretative review. Climate Research, 11, 19-30.

Ajwad, M. I., Kurukulasuriya, P., Basist, A., Dinar, A., Kogan, F., Mendelsohn, R. \& Williams, C. (2004). Crosssectional Analyses of Climate Change Impacts. The World Bank.

Akaike, H. (1973). Information Theory and the Maximum Likelihood Principle. In B.N Petrov and F.Csaki (Ed.), In 2nd International Symposium on Information Theory, (pp. 267-281). Budapest: AkailseoniaiKiudo.

Angélil, O., Stone, D., Wehner, M., Paciorek, C. J., Krishnan, H. \& Collins, W. (2017). An Independent Assessment of Anthropogenic Attribution Statements for Recent Extreme Temperature and Rainfall Events. Journal of Climate, 30, 5-16.

Appiah, D. O. (2017). Climate Policy Ambivalence in Sub-Saharan Africa. ICCG Reflection No.60.

Asseng, S., Foster, I. A. N. \& Turner, N. C. (2011). The Impact of Temperature Variability on Wheat Yields. Global Change Biology, 17(2), 997-1012.

Ater, P. I. \& Aye, G. C. (2012). Economic Impact of Climate Change on Nigerian Maize Sector: A Ricardian Analysis. WIT Transactions on Ecology and the Environment, 162.

Ayinde, O. E., Ajewole, O. O., Ogunlade, I. \& Adewumi, M. O. (2010). Empirical Analysis of Agricultural Production and Climate Change: A case Study of Nigeria. Journal of Sustainable Development in Africa, 12(6), 275-283.

Bacha, D., Namara, R., Bogale, A. \& Tesfaye, A. (2011). Impact of Small-scale Irrigation on Household Poverty: Empirical Evidence from the Ambo District in Ethiopia. Irrigation and Drainage, 60(1), 1-10.

Baltagi, B. (2008). Econometric Analysis of Panel Data. (Fourth ed.). John Wiley \& Sons.

Barrios, S., Ouattara, B. \& Strobl, E. (2008). The Impact of Climatic Change on Agricultural Production: Is it different for Africa? Food Policy, 33(4), 278-298.

Benin, S. (2015). Returns to Agricultural Public Spending in Africa South of the Sahara (Vol. 1491). Intl Food Policy Res Inst.

Bezabih, M., Falco, S. D. \& Mekonnen, A. (2014). On the Impact of Weather Variability and Climate Change on Agriculture: Evidence from Ethiopia. Environment for Development Discussion Paper-Resources for the Future (RFF), (14-15).

BoU. (2018). Bank of Uganda State of the Economy. Kampala.

Caffrey, P., Finan, T., Trzaska, S., Miller, D., Laker-Ojok, R. \& Huston, S. (2013). Uganda Climate Change Vulnerability Assessment Report. Kampala. USAID. ARCC. 
Calzolari, G., Magazzini, L. \& Mealli, F. (2001). Simulation-based Estimation of Tobit Model with Random. Econometric Studies: A Festschrift in Honour of Joachim Frohn, 8(349), 344-369.

Cameron, A. C. \& Trivedi, P. K. (2005). Microeconometrics: Methods and Applications. Cambridge University press.

Chang, E. H., Wang, C. H., Chen, C. L. \& Chung, R. S. (2014). Effects of Long-term Treatments of Different Organic Fertilizers Complemented with Chemical N Fertilizer on the Chemical and Biological Properties of Soils. Soil science and plant nutrition, 6. Soil Science and Plant Nutrition, 60(4), 499-511.

Dell, M., Jones, B. F. \& Olken, B. A. (2009). Temperature and Income: Reconciling New Cross-sectional and Panel Estimates. American Economic Review, 99(2), 198-204.

Deschenes, O. \& Greenstone, M. (2006). The Economic Impacts of Climate Change : Evidence from Agricultural Profits and Random Fluctuations of Weather, (131). MIT Joint Program on the Science and Policy of Global Change.

Dunne, J. P., Stouffer, R. J. \& John, J. G. (2013). Reductions in Labour Capacity from Heat Stress under Climate Warming. Nature Climate Change, 3(6), 563.

Easterling, W. E., Crosson, P. R., Rosenberg, N. J., McKenney, M. S., Katz, L. A. \& Lemon, K. M. (1993). Paper 2. Agricultural Impacts of and Responses to Climate Change in the Missouri-Iowa-Nebraska-Kansas (MINK) Region. Climatic Change, 24(1-2), 23-61.

Etwire, P. M., Fielding, D. \& Kahui, V. (2019). Climate Change, Crop Selection and Agricultural Revenue in Ghana: A Structural Ricardian Analysis. Journal of Agricultural Economics, 70(2), 488-506.

Exenberger, A., Pondorfer, A. \& Wolters, M. H. (2014). Estimating the Impact of Climate Change on Agricultural Production: Accounting for Technology Heterogeneity Across Countries. eeecon Working Paper. 2014-16.

Fang, S., Su, H., Liu, W., Tan, K. \& Ren, S. (2013). Infrared Warming Reduced Winter Wheat Yields and some Physiological Parameters, which were Mitigated by Irrigation and Worsened by Delayed Sowing. . PLoS One, 8(7), e67518.

Fezzi, C. \& Bateman, I. (2012). Non-linear Effects and Aggregation Bias in Ricardian Models of Climate Change. Centre for Social and Economic Research on the Global Environment. Working Paper 2012-02.

Fezzi, C. \& Bateman, I. (2015). The Impact of Climate Change on Agriculture: Nonlinear Effects and Aggregation Biasin Ricardian Models of Farmland Values, 2(1), 57-92.

Friedman, M. \& FRIEDMAN, M. (1953). Essays in Positive Economics. University of Chicago Press.

Gasper, R., Blohm, A. \& Ruth, M. (2011). Social and Economic Impacts of Climate Change on the Urban Environment. Current Opinion in Environmental Sustainability, 3(3), 150-157.

GoU. (2013). The Uganda National Land Policy. Ministry of Lands, Housing and Urban Development. Republic of Uganda.

GoU. (2015). Second National Development Plan - Uganda. National Planning Authority Uganda. Retrieved from http://npa.ug/wp-content/uploads/NDPII-Final.pdf on 15/3/2019

GoU. (2016). National Fertiliser Policy. Kampala: Ministry of Agriculture Animal Industry and Fisheries. Republic of Uganda.

GoU. (2017). Policy Statement for the Ministry of Agriculture, Animal Industry and Fisheries FY 2016/17. Ministry of Agriculture, Animal Industry and Fisheries.

Granados, R., Soria, J. \& Cortina, M. (2017). Rainfall Variability, Rainfed Agriculture and Degree of Human Marginality in North Guanajuato, Mexico. Singapore Journal of Tropical Geography, 38(2), 153-166.

Guloba, M. (2014). EFD. Retrieved from Analysis of Adaptation to Climate Variability And Change in Uganda.

Han, S. H., An, J. Y., Hwang, J., Kim, S. B. \& Park, B. B. (2016). The Effects of Organic Manure and Chemical Fertilizer on the Growth and Nutrient Concentrations of Yellow Poplar (Liriodendron tulipifera Lin.) in a Nursery System . Forest science and Technology, 12(3), 137-143.

Hanjra, M. A. \& Qureshi, M. E. (2010). Global water crisis and future food security in an era of climate change. Food policy, 35(5), 365-377.

Hansen, J., Sato, M., Ruedy, R., Schmidt, G. A. \& Lo, K. (2019). Global Temperature in 2018 and Beyond.

Hou, R., Ouyang, Z., Li, Y., Wilson, G. V. \& Li, H. (2012). Is the Change of Winter Wheat Yield under Warming Caused by Shortened Reproductive Period? Ecology and Evolution, 2(12), 2999-3008.

IPCC. (2013). Climate change 2013: The Physical Science Basis: Working Group I Contribution to the Fifth Assessment Report of the Intergovernmental Panel on Climate Change. (F. T. Stocker, D. Qin, ..., \& L. L. White , Eds.) Cambridge University Press.Cambridge,United Kingdom. 
IPCC. (2014). Climate Change 2014: Impacts, Adaptation and Vulnerability: Regional Aspects. (C. B. Field, D. J. Barros, ..., \& M. P. Midgley , Eds.) Cambridge University Press.Cambridge, United kingdom.

Jasso, G. (2004). The Tripartite Structure of Social Science Analysis. Sociological Theory, 22(3), 401-431.

Kabubo-Mariara, J. \& Kabara, M. (2018). Climate change and food security in Kenya. In Agricultural Adaptation to Climate Change in Africa, 55-80.

Kabubo-Mariara, J., Mulwa, R. \& Falco S. D. (2016). The impact of Climate Change on Food Calorie Production and Nutritional Poverty: Evidence from Kenya. Environment for Development Discussion Paper Resources for the Future (RFF), 35.

Kurukulasuriya, P. \& Ajwad, M. I. (2007). Application of the Ricardian technique to estimate the impact of climate change on smallholder farming in Sri Lanka. Climatic Change, 81, 39-59.

Kurukulasuriya, P. \& Mendelsohn, R. (2008). A Ricardian analysis of the impact of climate change on African cropland. AfJARE, 2(1).

Lang, G. (2007). Where are Germany's gains from Kyoto? Estimating the effects of global warming on agriculture. Climatic Change, 84, 423-439.

Lippert, C., Krimly, T. \& Aurbacher, J. (2009). A Ricardian analysis of the impact of climate change on agriculture in Germany. Climate Change, 97, 593-610.

Maganga, A. \& Malakini, M. (2015). Agrarian Impact of Climate Change in Malawi: A Quantile Ricardian Analysis (No. 1008-2016-79992).

Mall, R. K., Singh, R., Gupta, A., Srinivasan, G. \& Rathore, L. S. (2006). Impact of Climate Change on Indian Agriculture: A Review. Climatic Change, 78(2-4), 445-478.

Massetti, E. \& Mendelsohn. (2011). Estimating Ricardian Models with Panel Data. National Bureau of Economic Research, Working Paper No.17101.

Matovu, J. M. (2013). Productivity, Growth and Welfare Effects of Climate Change: Analysis Using a Dynamic CGE model for Uganda.

McDonald, J. F. \& Moffitt, R. A. (1980). The Uses of Tobit Analysis. The Review of Economics and Statistics, 62(2), 318-321.

Mendelsohn, R., Arellano-Gonzalez, J. \& Christensen, P. (2010). A Ricardian Analysis of Mexican Farms. Environment and Development Economics, 15(2), 153-171.

Mendelsohn, Robert, Nordhaus, W. D. \& Shaw, D. (1994). The Impact of Global Warning on Agriculture: A Ricardian Analysis. American Economic Review, 84(4), 753-771.

Nielsen, J. Ø. \& Vigh, H. (2012). Adaptive Lives. Navigating the Global Food Crisis in a Changing Climate. Global Environmental Change, 22(3), 659-669.

Nyuor, B. A., Donkor, E., Aidoo, R., Saaka Buah, S., Naab, J., Nutsugah, S. \& Zougmoré, R. (2016). Economic impacts of climate change on cereal production: implications for sustainable agriculture in Northern Ghana. Sustainability, 8(8), 724.

Odhiambo, W., Nyangito, H. O. \& Nzuma, J. (2004). Sources and Determinants of Agricultural Growth and Productivity in Kenya (No. 34). Kenya Institute for Public Policy Research and Analysis.

Peña-López, I. (2009). World Development Report 2010: Development and Climate Change.

Raza, J. \& Siddiqui, W. (2014). Determinants of Agricultural Output in Pakistan: A Johansen Co-integration Approach. Academic Research International, 5(4), 30.

Rosenzweig, C. \& Parry, M. L. (1994). Potential Impact of Climate Change on World Food Supply. Nature, 367(6459), 133

Rowhani, P., Lobell, D. B., Linderman, M. \& Ramankutty, N. (2011). Climate Variability and Crop Production in Tanzania. Agricultural and Forest Meteorology, 151(4), 449-460.

Salami, A., Kamara, A. B. \& Brixiova, Z. (2010). Smallholder Agriculture in East Africa: Trends, Constraints and Opportunities. Tunis: African Development Bank.

Salvo M. D., Begalli D. \& Signorello, G. (2014). The Ricardian Analysis Twenty Years after the Original Model : Evolution , Unresolved Issues and Empirical Problems. Journal of Development and Agricultural, 6(3), 124-131.

Sanghi, A., Mendelsohn, R. \& Dinar, A. (1998). The Climate Sensitivity of Indian Agriculture: In Measuring the Impact of Climate Change on Indian Agriculture. World Bank Technical paper. World Bank, Washington, DC.

Schlenker, W. \& Roberts, M. J. (2008). Estimating the Impact of Climate Change on Crop Yields: The Importance of Non-Linear Temperature Effects. National Bureau of Economic Research, Working Paper No. 13799. 
Schwarz, G. (1978). Estimating the Dimension of a Model. The Annals of Statistics, 6(2), 461-464.

Sharma, U., Paliyal, S. S., Sharma, S. P. \& Sharma, G. D. (2014). Effects of Continuous Use of Chemical Fertilizers and Manure on Soil Fertility and Productivity of Maize-wheat under Rainfed Conditions of the Western Himalayas. Communications in Soil science and Plant Analysis, 45(20), 2647-2659.

Shephard, R. W. (1970). Proof of the Law of Diminishing Returns. Zeitschrift für Nationalökonomie, 30(1-2), 734.

Skonhoft, A. (2008). Sheep as Capital Goods and Farmers as Portfolio Managers: A Bioeconomic Model of Scandinavian Sheep Farming. Agricultural Economics, 38(2), 193-200.

Skoufias, E. (2012). The Poverty and Welfare Impacts of Climate Change: Quantifying the Effects, Identifying the Adaptation Strategies. The World Bank.

Splett, N. S., Barry, P. J., Dixon, B. L. \& Ellinger, P. N. (1994). A joint Experience and Statistical Approach to Credit Scoring. Agricultural Finance Review (USA).

Sy, A. (2016). Africa: Financing Adaptation and Mitigation in the World's Most Vulnerable Region. Africa: Brookings Institution, Africa Growth Initiative.

Teixeira, E. I., Fischer, G., Van Velthuizen, H., Walter, C. \& Ewert, F. (2013). Global Hot-spots of Heat Stress on Agricultural Crops due to Climate Change. Agricultural and Forest Meteorology, 170, 206-215.

Thomson, K. J. (2010). Climate Change and Agriculture: An Economic Analysis of Global Impacts, Adaptation and Distributional Effects. By R. Mendelsohn and A. Dinar. Cheltenham, UK: Edward Elgar (2009), pp. 256,£ 53.96 (online discount price). ISBN 978-1-84720-670-1. Experimental Agriculture, 46(2), 259259.

Thurlow, J., Zhu, T. \& Diao, X. (2012). Current Climate Variability and Future Climate Change: Estimated Growth and Poverty Impacts for Zambia. Review of Development Economics, 16(3), 394-411.

Tian, Y., Zheng, C., Chen, J., Chen, C., Deng, A., Song, Z. \& Zhang, W. (2014). Climatic Warming Increases Winter Wheat Yield but Reduces Grain Nitrogen Concentration in East China. PloS one, 9(4), e95108.

Tobin, J. (1958). Estimation of Relationships for Limited Dependent Variables. Econometrica: journal of the Econometric Society, 24-36.

Tokunaga, S., Okiyama, M. \& Ikegawa, M. (2015). Dynamic Panel Data Analysis of the Impacts of Climate Change on Agricultural Production in Japan. Japan Agricultural Research Quarterly: JARQ, 49(2), 149157.

UBOS. (2009a). The Uganda National Panel Survey ( UNPS ) 2009-Documentation. Uganda Bureau of Statistics.

UBOS. (2009b). Statistical Abstract. Uganda Bureau of Statistics.

UBOS. (2010). Uganda National Panel Survey Manual Instructions for Agriculture Questionnaire. Uganda Bureau of Statistics .

UBOS. (2013). Uganda National Panel Survey 2011/2012 .Wave iii Report. Uganda Bureau of Statistics.

UBOS. (2015). The Uganda National Panel Survey ( UNPS ) 2013 /14 Basic Information Document. Uganda Bureau of Statistics.

Union, A. (2003). Comprehensive Africa Agriculture Development Programme. Midrand, South Africa: NEPAD.

Wang, J., Mendelsohn, R., Dinar, A., Huang, J., Rozelle, S. \& Zhang, L. (2008). Can China Continue Feeding Itself? The impact of Climate Change on Agriculture. World Bank.

White, E. B. (2007). Charlotte ' s Web, 1-157 . Retrieved 3 15, 2019, from https://lostcontact.mit.edu/afs/adrake.org/usr/rkh/Books/books/Charlotte\%27s\%20Web.pdf

World Bank. (2010). Worl Bank Development Indicators 2010. Washington, D.C, USA.

World Bank. (2011). World Bank Data Team. Living Standard Measurement Study: When Data Collection is Intrepid:. Retrieved from https://blogs.worldbank.org/opendata/living-standard-measurementstudy-when-data-collection-intrepid on 4/4/2019

World Bank. (2011). World Bank Data Team: Living Standard Measurement Study. When Data Collection is Intrepid. Retrieved from L: https://blogs.worldbank.org/opendata/living-standard-measurementstudy-when-data-collection-intrepid

Zivin, G. J. \& Neidell, M. (2014). Temperature and the Allocation of Time: Implications for Climate Change. Journal of Labor Economics, 32(1), 1-26. 